\title{
Analisa Pembangunan Aplikasi Pengolahan Data Akademik Berbasis Web
}

\author{
Anisya1, Bayu Febriadi' $^{2}$, Wahyu Hidayat ${ }^{3}$ \\ 1,3Program Studi Teknik Informatika, Fakultas Teknologi Industri ITP \\ 2Prodi Sistem Informasi Fakultas Ilmu Komputer Universitas Lancang Kuning \\ anisya@itp.ac.id, bayufebriadi9@gmail.com
}

\begin{abstract}
Vocational High School (SMK) is one form of a formal education unit that provides vocational education as a continuation of (Junior High School) SMP / MTs and equal. One of them is SMK N 1 Koto Baru. In the processing of academic data using Microsoft Excel and Microsoft Word applications, the number of students approximately 550 students are divided into 9 departments so it takes a long time in the processing of academic data. This study aims to analyze the development of SMK N 1 Koto Baru to process academic data such as attendance, assessment of daily exams, duties, and final exams. The development of this system uses PHP programming language and MySQL database. The results obtained from this study in the form of student report cards per academic year.
\end{abstract}

Keywords : Application, Academic, PHP, MySQL

\begin{abstract}
Abstrak
Sekolah Menengah Kejuruan (SMK) merupakan salah satu bentuk satuan pendidikan formal yang menyelenggarakan pendidikan kejuruan sebagai lanjutan dari SMP/MTs dan sederajat. Salah satunya SMK N 1 Koto Baru. Dalam pengolahan data akademik masih menggunakan aplikasi Microsoft Excel dan Microsoft Word, dilihat dari jumlah siswa lebih kurang 550 siswa yang terbagi menjadi 9 jurusan sehingga membutuhkan waktu yang cukup lama dalam pengolahan data akademik. Penelitian ini bertujuan untuk menganalisa pembangunan aplikasi pengolahan data akademik berbasis web yang mampu memudahkan pihak akademik dan keuangan SMKN 1 Koto Baru untuk mengolah data akademik seperti absensi, penilaian ujian harian, tugas, dan ujian akhir. Pembangunan sistem ini menggunakan bahasa pemrograman PHP dan database MySQL. Hasil yang diperoleh dari penelitian ini berupa rapor siswa per tahun akademik.
\end{abstract}

Kata Kunci : Aplikasi, Akademik, PHP, MySQL

\section{PENDAHULUAN}

SMK N 1 Koto Baru merupakan salah satu Sekolah Menengah Kejuruan yang berada di daerah Dharmasraya yang memiliki 9 jurusan diantaranya yaitu Agribisnis Tanaman Perkebunan, Agribisnis Tanaman Pangan dan Hortikultura, Agribisnis Pembibitan Tanaman dan Kultur Jaringan, Agribisnis Ternak Rumanisia, Agribisnis Ternak Unggas, Teknologi Pengolahan Hasil Pertanian, Teknik Kendaraan Ringan, Teknik Otomotif dan Sepeda Motor, dan Multimedia dengan jumlah keseluruhan siswa mencapai 550 siswa yang terdiri dari 188 siswa di kelas satu, dan kelas dua sebanyak 182 siswa, 
sedangkan untuk kelas tiga sebanyak 180 siswa (ANISYA, A., \& Hidayat, W, 2017).

Pada SMK N 1 Koto Baru pengolahan data-data akademik seperti data siswa, data nilai ulangan harian, data ujian tengah semester, data ujian akhir semester dan data nilai ekstrakurikuler masih bersifat manual dan data-data siswa tersebut baru dikelola dengan Microsoft Word dan Microsoft Excel.

Salah satu contoh permasalahan yang dialami yaitu pada saat pendataan nilai seperti laporan nilai yang didapat oleh siswa masih diinput secara manual. Nilai siswa yang didapat dari hasil ujian semester, ulangan harian, nilai tugastugas, dan nilai-nilai lainya yang diserahkan terlebih dahulu kepada tata usaha oleh guru mata pelajaran untuk di olah nilainya yang menjadi laporan sebanyak dua rangkap. Rangkap satu untuk diserahkan kepada wali kelas dan rangkap yang satunya lagi sebagai arsip. Guru wali kelas masih harus membuat laporan tentang nilai dari anak asuhnya atau kepada wali murud yang di dapat selama satu semester sebanyak tiga rangkap. Rangkap pertama diserahkan kepada siswa, rangkap kedua diserahkan kepada diserahkan kepada kepala sekolah sedangkan yang terakhir digunakan sebagai arsip. dengan prosedur seperti ini maka akan memakan waktu dan tempat yang cukup banyak oleh sebab itu proses yang dilakukan dirasa kurang efektif dan efesien maka dibutuhkan sebuah sistem untuk memangkas waktu dan tempat menjadi lebih sedikit dalam proses pengolahan data (ANISYA, A., \& Hidayat, W, 2017).

Jurnal ini merupakan lanjutan dari jurnal yang telah terbit sebelumnya. Pada jurnal ini membahas mengenai pembangunan aplikasi berdasarkan rancangan dari hasil jurnal sebelumnya. Pembangunan aplikasi ini menggunakan bahasa pemrograman PHP dan database MySQL.

\section{METODOLOGI PENELITIAN}

\subsection{Konsep Dasar Perangkat Lunak}

Software adalah komponen dalam proses sistem yang berupa programprogram dan teknik-teknik lain untuk mengontrol sistem Secara umum, istilah software menyatakan cara-cara yang menghasilkan hubungan yang lebih efisien antara manusia dan mesin komputer (Simarmata, 2010).

\subsection{Proses Perangkat Lunak}

Serangkaian Kegiatan dan hasil - hasil relevannya menghasilkan perangkat lunak sebagian besar dilakukan oleh perekayasa perangkat lunak ada 4 kegiatan aktifitas pada proses perangkat lunak (Nugroho, 2010):

1. Spesifikasi perangkat lunak yaitu fungsionalitas perangkat lunak dan batasan kemampuan operasinya harus didefenisikan.

2. Pengembangan perangkat lunak yaitu perangkat lunak yang memenuhi spesifikasi harus di produksi

3. Validasi perangkat lunak yaitu perangkat lunak harus divalidasi untuk menjamin bahwa perangkat lunak melakukan apa yang diinginkan pelanggan. 
4. Evaluasi Perangkat Lunak yaitu perangkat lunak harus berkembang untuk memenuhi kebutuhan pelanggan

\subsection{Jenis Model Perangkat Lunak}

1. Model Aliran Kerja yaitu menunjukan kegiatan pada proses bersama dengan input, output dan ketergantungannya. Mempresentasikan pekerjaan manusia

2. Model Aliran Data yaitu Mempresentasikan proses sehingga suatukegiatan yang melakukan transformasi data. Menunjukan Output

3. Model peran/aksi yaitu merepresetasikan peran orang yang terlibat pada perangkat lunak dan kegiatan yang menjadi tanggung jawab mereka.

\subsection{Metode Penelitian}

Dalam penulisan penelitian, jenis penelitian yang dilakukan adalah membuat Rekayasa Perangkat Lunak (RPL) Pengolahan Data Akademik Berbasis Web di SMK N 1 Koto Baru Kabupaten Dharmasraya.

\section{HASIL DAN PEMBAHASAN}

Pada pembahasan ini, user dapat melihat tampilan aplikasi ini jika dijalankan. Pada pembahasan ini akan dijelaskan satu persatu tampilan halaman aplikasi.

\subsection{Halaman Login}

Halaman login merupakan halaman yang pertama kali muncul pada sistem. Pengguna harus mengisikan username dan password untuk bisa masuk kedalam sistem. Adapun bentuk tampilan dari halaman login sebagai berikut:

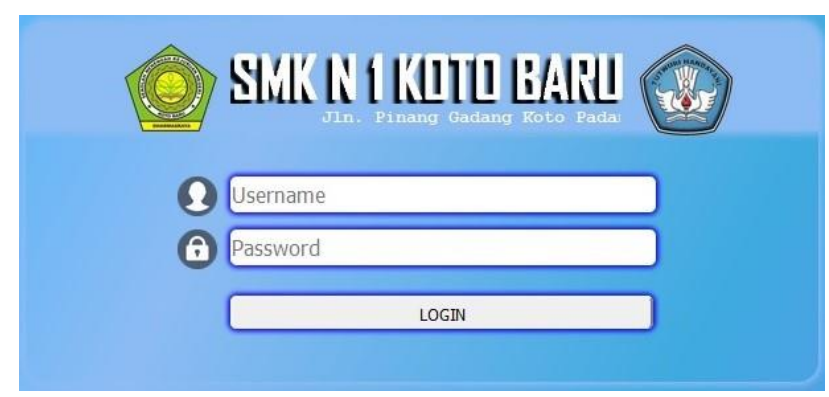

Gambar 1. Halaman Login

\subsection{Halaman Utama Admin}

Halaman utama admin merupakan halaman yang berfungsi untuk mengatur seluruh kegiatan mulai dari tambah data, rubah data, dan hapus data selain data nilai dan absensi siswa. 


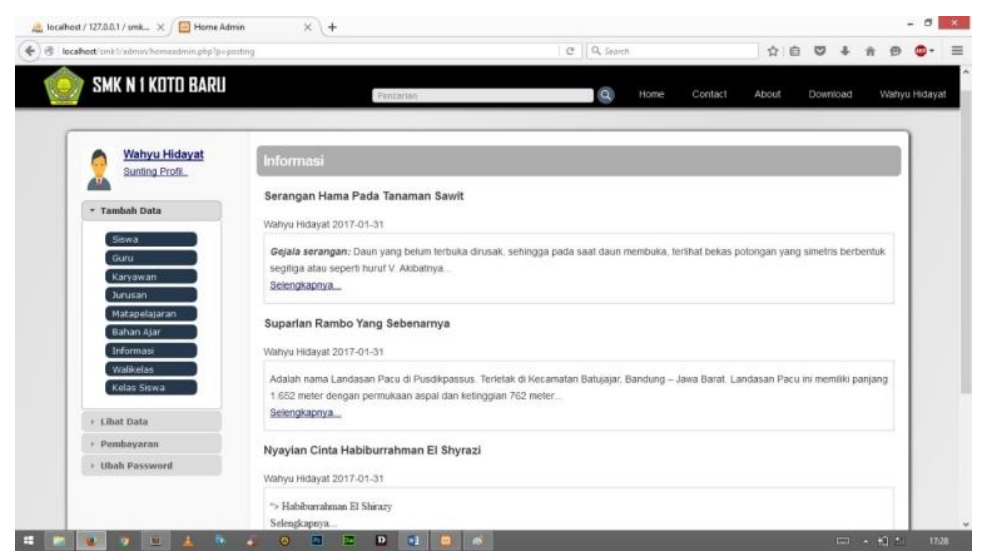

Gambar 2. Halaman Utama Admin

\subsection{Halaman Download}

Pada halaman ini pengguna dapat mengunduh berkas yang berupa bahan ajar yang sudah di unggah oleh karyawan atau guru yang bersangkutan.

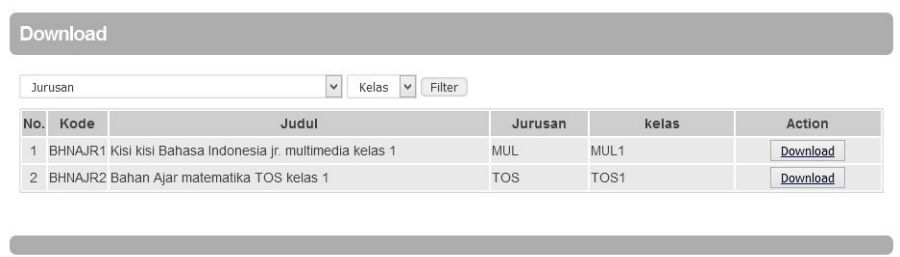

Gambar 3. Halaman Download

Script untuk mengunduh berkas :

$<$ ?php

include(".././config/koneksi.php");

if (isset(\$_GET['kode_bahan'])\} \{

\$kode_bahan=\$_GET['kode_bahan'];

\$unduh=mysql_query("SELECT * FROM bahan_ajar WHERE

kode_bahan='\$kode_bahan'");

if (\$file=mysql_fetch_assoc(\$unduh) $)\{$

$\$$ tipe $=\$$ file['tipe'];

\$ukuran=\$file['ukuran'];

\$namafile=\$file['namafile'];\}

header("Content-Disposition: attachment; filename=\$namafile");

header("Content-length: \$ukuran");

header("Content-type: \$tipe");

readfile("../bajar/\$namafile");\}?>

\subsection{Halaman Tambah Siswa}

Halaman tambah siswa berfungsi untuk menambahkan siswa yang baru masuk ke sekolah SMK N 1 Koto Baru. 


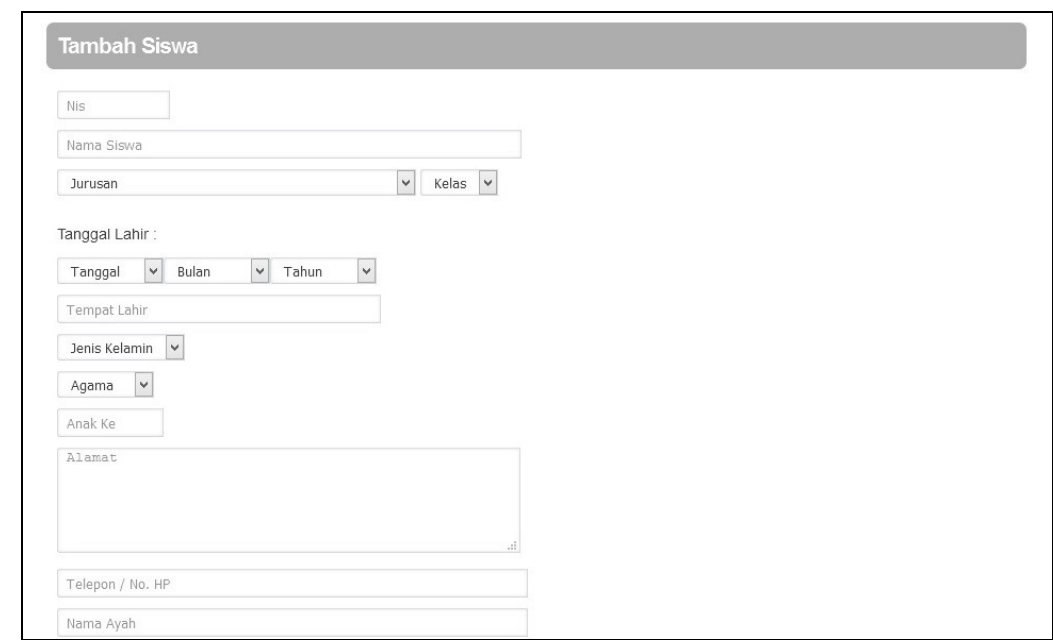

Gambar 4. Tambah Siswa

Script untuk menambah

siswa :

$<$ ?php

\$cek=mysql_query("SELECT * FROM siswa WHERE nis");

\$ns=mysql_fetch_array( $\$$ cek);

\$niss $=\$$ ns['nis'];

mysql_query("INSERT INTO siswa VALUES ('\$nis','\$nama_siswa','\$tahun-

\$bulan-

\$tanggal','\$s_tempat_lahir','\$s_jk','\$s_agama','\$s_anak_ke','\$s_alamat','\$s_tele pon','\$s_nama_ayah','\$s_nama_ibu','\$s_pekerjaan_ayah','\$s_pekerjaan_ibu','\$ s_telepon_ortu','Uploads/\$fileName','\$s_password')");

mysql_query("INSERT INTO sijur VALUES ('\$nis','\$jr')");

mysql_query("INSERT INTO sikel VALUES ('\$nis','\$jr\$kls')");

move_uploaded_file(\$_FILES['foto']['tmp_name'],

"Uploads/".\$_FILES ['foto']['name']);

echo"<script lenguange='javascript'>alert('Data Berhasis Disimpan

!') $<$ script $>$;

echo "<script> document.location.href='homeadmin.php?p=tambahsiswa'

$</$ script $>$ ";

\}

\}

?>

\subsection{Halaman Lihat Siswa}

Halaman ini berguna untuk melihat daftar siswa yang berada di SMK N 1 Koto Baru yang bisa dilihat berdasarkan kelas, jurusan, dan juga tahun ajaran. 


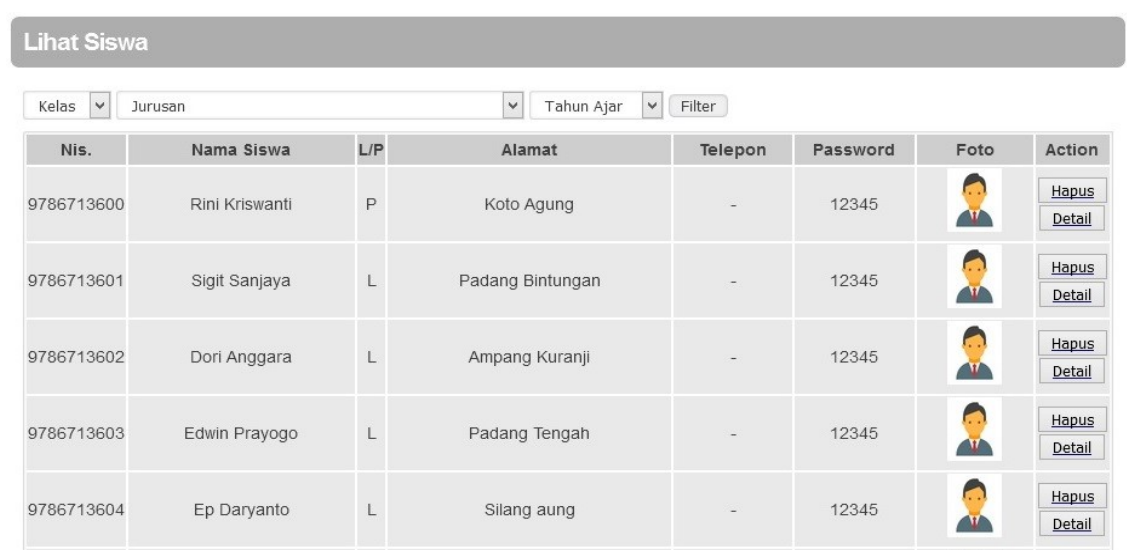

Gambar 5. Lihat siswa

\subsection{Halaman Pembayaran Siswa}

Halaman ini diguakan untuk siswa yang akan melakukan pembayaran uang sekolah.

\begin{tabular}{|c|c|c|c|c|c|}
\hline \multicolumn{6}{|c|}{ Pembayaran Siswa } \\
\hline \multicolumn{2}{|c|}{9992498408} & \multicolumn{4}{|l|}{ Cari } \\
\hline No. & Nis & Nama Siswa & Jurusan & Kelas & Action \\
\hline \multicolumn{3}{|c|}{19992498408 David Genola } & Agribisnis Pembibitan Tamanan dan Kultur Jaringan & 1 & Bayar \\
\hline
\end{tabular}

Gambar 6. Pembayaran Siswa

Bagi siswa yang akan melakukan pembayaran maka pihak pengguna (karyawa/admin) akan melakukan pencarian data siswa berdasarkan nis yang diisikan pada kolom pencarian yang dapat dilihat pada gambar 6 di atas. Apabila data siswa sudah ditemukan maka dengan menekan tombol bayar maka pengguna akan dialihkan ke halaman selanjutnya seperti yang ditunjukan oleh gambar 7 di bawah ini.

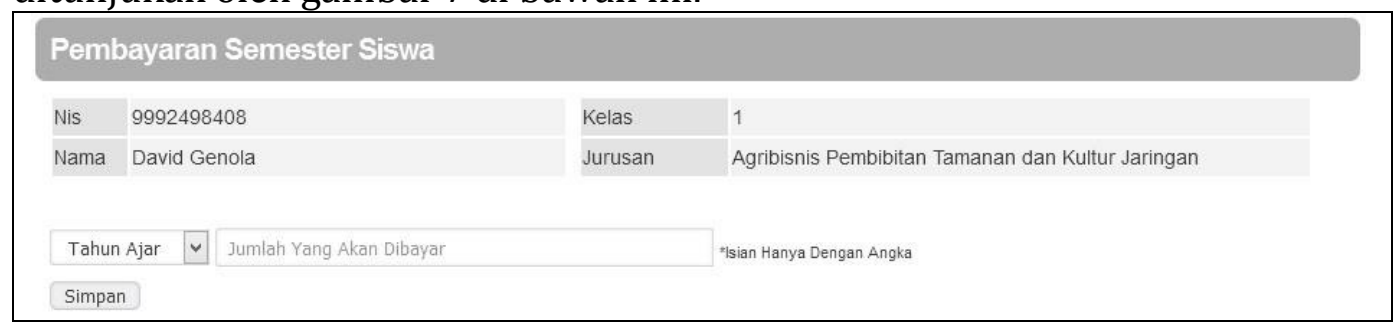

Gambar 7. Pembayaran Semester Siswa

\subsection{Halaman Laporan Pembayaran}

Dibawah ini merupakan bentuk dari laporan pembayaran untuk lebih jelasnya dapat dilihat pada gambar 8 berikut ini. 


\begin{tabular}{|c|c|c|c|c|c|}
\hline \multicolumn{6}{|c|}{$\begin{array}{l}\text { SMK N } 1 \text { KOTO BARU } \\
\text { LAPORAN PEMBAYARAN SEMESTER }\end{array}$} \\
\hline \multicolumn{6}{|c|}{ Jln. Pinang Gadang Koto Padang, Kec. Koto Baru, Kab. D harmasraya, Prov. Sumatera Barat (27674) } \\
\hline Kelas & 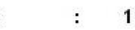 & 1 & & & \\
\hline \multicolumn{2}{|c|}{ Jurusan } & Agribis nis Pembibitan Tamanan & & & \\
\hline \multicolumn{6}{|c|}{ Tahun Ajaran : } \\
\hline No. & Nis & Nama & Sisa & Total & Sisa \\
\hline 1 & 9992498408 & David Genola & 500000 & 500000 & 0 \\
\hline 2 & 9993017786 & M.Al-Qorni & 500000 & 500000 & 0 \\
\hline 3 & 9982491598 & M.Dede & 350000 & 500000 & 150000 \\
\hline 4 & 9992499724 & Mega Mistika Sari & 450000 & 500000 & 50000 \\
\hline 5 & 9992711964 & Meiza Inayah Putri & 300000 & 500000 & 200000 \\
\hline \multicolumn{3}{|c|}{ Jumlah } & 2100000 & 2500000 & 400000 \\
\hline
\end{tabular}

Gambar 8. Laporan Pembayaran

\subsection{Halaman Utama Guru}

Halaman utama guru merupakan halaman yang pertama kali muncul saat guru masuk kedalam sistem. Dan pada saat itu ditapilkan pula informasi informasi yang telah di posting oleh para guru lain dan juga karyawan/admin.

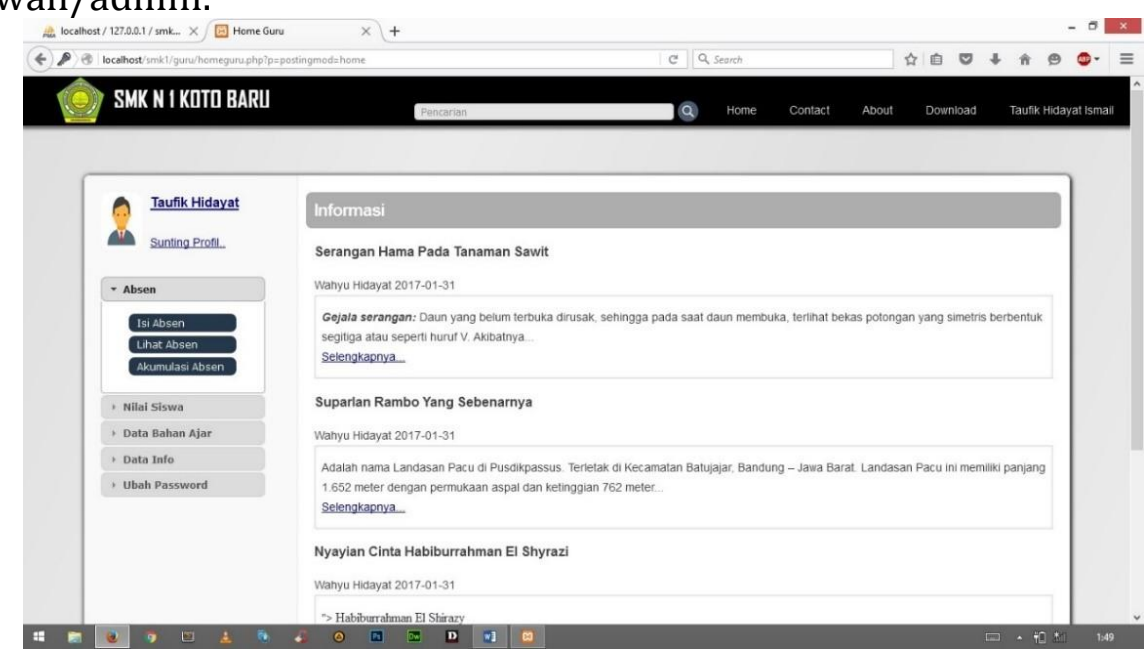

Gambar 9. Halaman Utama Guru

\subsection{Halaman Isi Absen}

Pada halaman ini diperuntukan sebagai sarana pengisian absen siswa oleh guru yang mengajar di SMK N 1 Koto Baru.

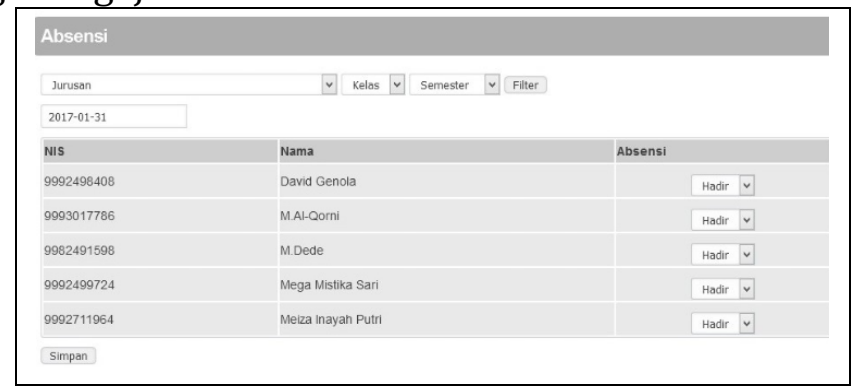

Gambar 10. Isi absen 
Script halaman isi absen :

foreach $(\$ a b$ as $\$ \mathrm{i}=>\$ \mathrm{v})\{$

\$cek = mysql_query("SELECT * FROM absen WHERE tanggal ='\$tgl' AND

nip ='\$id' AND nis ='\$i'");

if (mysql_num_rows $(\$ c e k)>0)\{$

if $(\$ \mathrm{v}==1)$ \{mysql_query("UPDATE absen SET hadir='1',izin='0',alfa='0'

WHERE

nis='\$i' AND nip='\$id' AND tanggal='\$tgl'");

\} else if ( $\$ \mathrm{~V}==2$ ) \{mysql_query("UPDATE absen SET

hadir='0',izin='1',alfa='0' WHERE nis='\$i'AND nip='\$id' AND

tanggal='\$tgl'");

\} else \{mysql_query("UPDATE absen SET hadir='0',izin='0',alfa='1'

WHERE

nis='\$i'AND nip='\$id' AND tanggal='\$tgl'");\}

\} else \{

if $(\$ v==1)\{$

ysql_query("INSERT INTO absen (nis,kode_mapel,hadir,izin,alfa,nip,tanggal)

VALUES ('\$i','\$kode_mapel','1','0','0','\$id','\$tgl')");

\} else if ( $\$ \mathrm{v}==2$ ) \{mysql_query("INSERT INTO absen (nis,kode_mapel, hadir, izin, alfa, nip, tanggal ) VALUES ('\$i','\$kode_mapel','0','1','0','\$id','\$tgl')");

\} else \{mysql_query("INSERT INTO absen (nis, kode_mapel, hadir, izin, alfa, nip, tanggal ) VALUES ('\$i','\$kode_mapel','0','0','1','\$id','\$tgl')"); \}

\subsection{Halaman Lihat Absen}

Halaman ini digunakan untuk melihat absensi siswa pada tanggal, kelas dan jurusan oleh masing - masing guru yang mengajar di SMK N 1 Koto Baru.

\begin{tabular}{|c|c|c|c|}
\hline Lihat Absensi & & & \\
\hline Tanggal & Kelas $\checkmark$ Jurusan & $v G 0$ & \\
\hline Nama & & Tanggal & Absensi \\
\hline David Genola & & 2017-02-01 & Hadir \\
\hline M.Al-Qorni & & 2017-02-01 & Hadir \\
\hline M.Dede & & 2017-02-01 & Hadir \\
\hline Mega Mistika Sari & & 2017-02-01 & Alfa \\
\hline Meiza Inayah Putri & & 2017-02-01 & Hadir \\
\hline
\end{tabular}

Gambar 11. Lihat Absen

Script untuk melihat absensi siswa :

if (isset(\$_POST['go'])) \{

\$jr=\$_POST['kd_jurusan'];

$\$ \mathrm{kl}=\$ \_P O S T\left[' k k e l a s^{\prime}\right]$;

\$tgl=\$_POST['tgl'];

\$abs=mysql_query("SELECT * FROM absen

JOIN gpel ON absen.kode_mapel = gpel.kode_mapel

JOIN matapelajaran ON absen.kode_mapel = matapelajaran.kode_mapel JOIN

siswa ON absen.nis = siswa.nis WHERE gpel.nip = '\$id' AND 
matapelajaran.kode_jurusan = '\$jr' AND matapelajaran.kode_kelas = '\$jr\$kl' AND absen.tanggal = '\$tgl'");

\subsection{Halaman Akumulasi Absen}

Halaman akumulasi absen adalah halaman yang berfungsi untuk melihat akumulasi absensi siswa selama satu semester.

\begin{tabular}{|c|c|c|c|c|c|c|c|c|c|}
\hline \multicolumn{10}{|c|}{ Akumulasi Absensi } \\
\hline Semester & $\checkmark$ & Kelas $\checkmark$ & Jurusan & & $\checkmark$ & GO & & & \\
\hline \multicolumn{4}{|l|}{ Nama } & \multicolumn{3}{|l|}{ Semester } & Hadir & Alfa & Izin \\
\hline \multicolumn{4}{|l|}{ M.Dede } & \multicolumn{3}{|l|}{ 2014/20151 } & 2 & 1 & 0 \\
\hline \multicolumn{4}{|c|}{ David Genola } & \multicolumn{3}{|l|}{$2014 / 20151$} & 2 & 0 & 1 \\
\hline \multicolumn{4}{|c|}{ Mega Mistika Sari } & \multicolumn{3}{|l|}{$2014 / 20151$} & 2 & 1 & 0 \\
\hline \multicolumn{4}{|c|}{ Meiza Inayah Putri } & \multicolumn{3}{|l|}{$2014 / 20151$} & 2 & 0 & 1 \\
\hline \multicolumn{4}{|l|}{ M.AI-Qorni } & \multicolumn{3}{|l|}{$2014 / 20151$} & 3 & 0 & 0 \\
\hline
\end{tabular}

Gambar 12. Akumulasi Absen

Script halaman akumulasi absensi :

if (isset(\$_POST['go']))\{

$\$ \mathrm{jr}=\$$ _POST['kd_jurusan'];

$\$ \mathrm{kl}=\$ \_P O S T[' k k e l a s '] ;$

\$tgl=\$_POST['kd_semester'];

\$abs=mysql_query("SELECT *, SUM(hadir) AS h, SUM(alfa) AS a, SUM(izin)

AS i FROM absen

JOIN gpel ON absen.kode_mapel = gpel.kode_mapel

JOIN matapelajaran ON absen.kode_mapel = matapelajaran.kode_mapel JOIN siswa ON absen.nis = siswa.nis WHERE gpel.nip = '\$id' AND

matapelajaran.kode_jurusan = '\$jr' AND matapelajaran.kode_kelas = '\$jr\$kl' AND matapelajaran.kode_semester = '\$tgl' GROUP BY absen.nis");

\subsection{Halaman Input Nilai}

Untuk masalah nilai sistem ini menyediakan halaman yang berfungsi untuk memasukan nilai - nilai siswa pada masing masing matapelajaran yang di ajarkan di sekolahan. Untuk lebih jelasnya dapat dilihat pada gambar 13 .

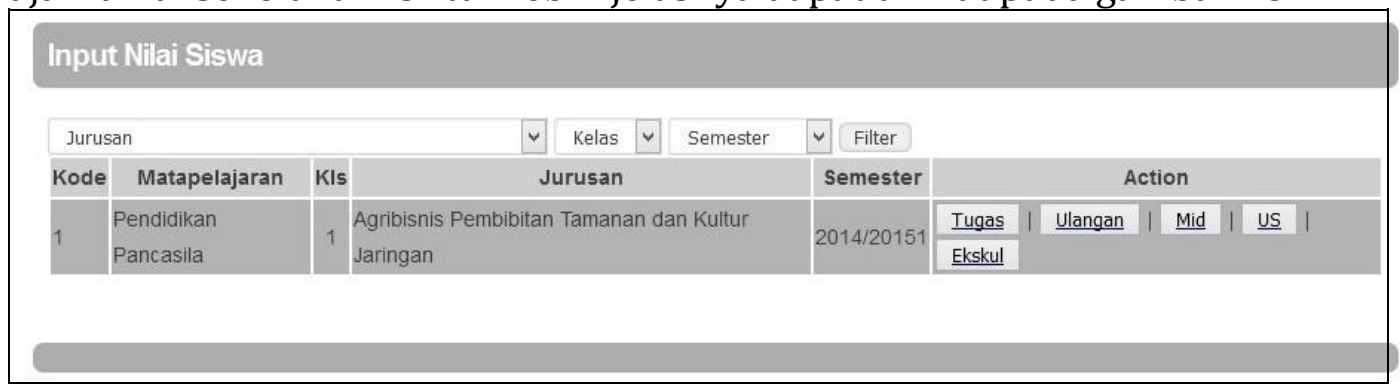

Gambar 13. Pilihan Input Nilai 


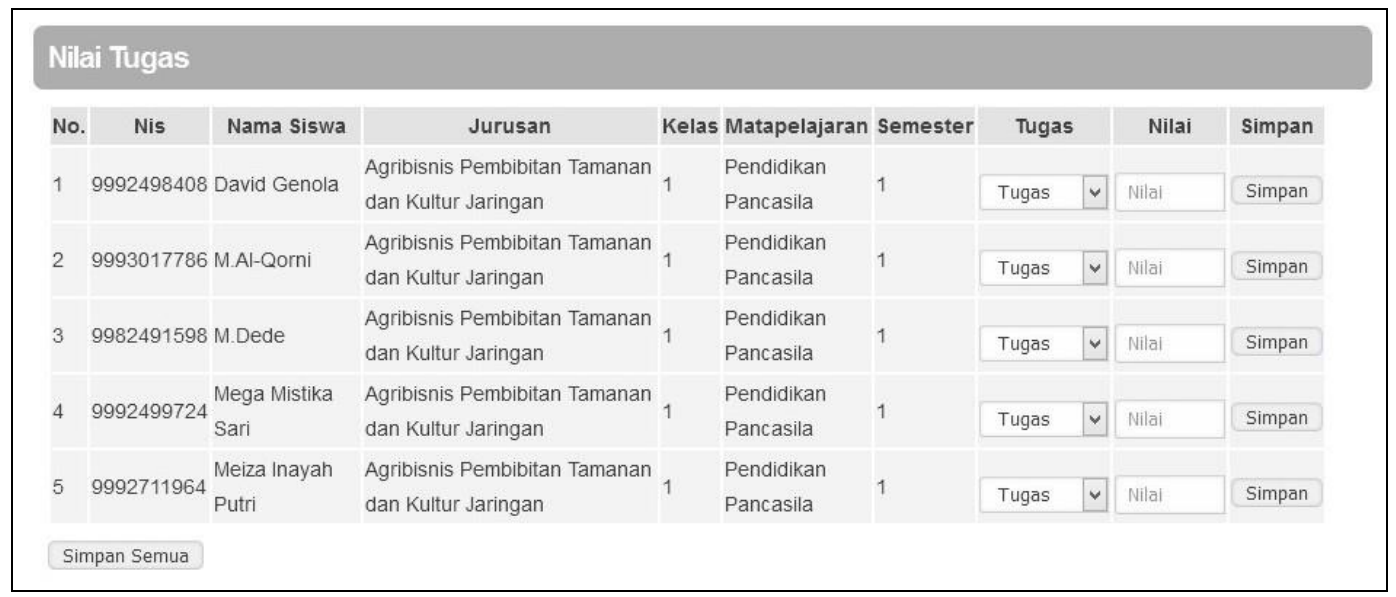

Gambar 14. Input Nilai

Script pengelompokkan siswa :

if (isset(\$_POST['filter'])\} \{

\$jr=\$_POST['kd_jurusan'];

\$kl=\$_POST['kkelas'];

$\$$ sm $=\$$ _POST ['kd_sm'];

\$sqlkel="SELECT * FROM guru INNER JOIN gpel ON gpel.nip=guru.nip

INNER JOIN matapelajaran ON gpel.kode_mapel = matapelajaran.kode_mapel

INNER JOIN tkelas ON matapelajaran.kode_kelas=tkelas.kode_kelas

INNER JOIN jurusan ON

matapelajaran.kode_jurusan=jurusan.kode_jurusan WHERE

guru.nip='\$id' and tkelas.kelas='\$kl' and jurusan.kode_jurusan='\$jr' and

matapelajaran.kode_semester='\$sm'";

Script memasukan nilai siswa :

\$sqlnilai=mysql_query("SELECT * FROM nilai WHERE nis='\$nsiswa' AND kode_mapel='\$kdpel'");

\$sqlnilai=mysql_query("SELECT * FROM nilai WHERE nis='\$nsiswa' AND kode_mapel = '\$kdpel'");

if (mysql_num_rows (\$sqlnilai) $>0)\{$

if ( $\$$ ulangan=='u1') \{

mysql_query("UPDATE nilai SET tugas1='\$nil' WHERE nis='\$nsiswa' and kode_mapel='\$kdpel'");

\}elseif ( $\$$ ulangan=='u2') \{

mysql_query("UPDATE nilai SET tugas2='\$nil' WHERE nis='\$nsiswa' and

kode_mapel='\$kdpel'");

\}elseif (\$ulangan=='u3') \{

mysql_query("UPDATE nilai SET tugas3='\$nil' WHERE nis='\$nsiswa'

and kode_mapel='\$kdpel'");\}

\} else \{

if (\$ulangan=='u1') \{ 
mysql_query("INSERT INTO nilai SET kode_nilai='\$id_bahan', nis='\$nsiswa', kode_kelas='\$kdlas',kode_jurusan='\$kdjur',kode_semester='\$kdsem',kode_ mapel='\$kdpel', nip='\$id', tugas1='\$nil'");

\}elseif (\$ulangan=='u2') \{

mysql_query("INSERT INTO nilai SET kode_nilai='\$id_bahan', nis='\$nsiswa', kode_kelas='\$kdlas',kode_jurusan='\$kdjur',kode_semester='\$kdsem',kode_ mapel='\$kdpel', nip='\$id', tugas2='\$nil'");

\}elseif (\$ulangan=='u3') \{

mysql_query("INSERT INTO nilai SET kode_nilai='\$id_bahan', nis='\$nsiswa', kode_kelas='\$kdlas',kode_jurusan='\$kdjur',kode_semester='\$kdsem',kode_ mapel='\$kdpel', nip='\$id', tugas3='\$nil'");

\subsection{Halaman Lihat Nilai}

Setelah dilakukan penginputan nilai maka guru juga bisa melihat nilai - nilai siswa yang telah diberikan oleh guru tersebut. Berikut ini adalah tampilan halama lihat nilai seperti yang ditunjukan oleh gambar 15.

\begin{tabular}{|c|c|c|c|c|c|c|c|c|c|c|c|c|}
\hline \multicolumn{13}{|c|}{ Lihat Nilai Siswa } \\
\hline \multicolumn{2}{|c|}{ Kelas $\checkmark$} & \multicolumn{2}{|l|}{ Jurusan } & \multirow[t]{2}{*}{$\checkmark$} & \multirow{2}{*}{$\begin{array}{l}\text { GO } \\
\text { UH } 1\end{array}$} & \multirow[b]{2}{*}{ UH 2} & \multirow[b]{2}{*}{ UH 3} & \multirow[b]{2}{*}{ TGS 1} & \multirow[b]{2}{*}{ TGS 2} & \multirow[b]{2}{*}{ TGS 3} & \multirow[b]{2}{*}{ MID } & \multirow[b]{2}{*}{ Ujian } \\
\hline No & Nama & Siswa & Mata Pelajaran & & & & & & & & & \\
\hline 1 & David & Genola & Pendidikan Pancasila & & 0 & 0 & 0 & 89 & 89 & 0 & 0 & 0 \\
\hline 2 & M.AI-C & orni & Pendidikan Pancasila & & 0 & 0 & 0 & 78 & 78 & 0 & 0 & 0 \\
\hline 3 & M.Ded & & Pendidikan Pancasila & & 0 & 0 & 0 & 67 & 45 & 0 & 0 & 0 \\
\hline 4 & Mega & Mistika Sari & Pendidikan Pancasila & & 0 & 0 & 0 & 50 & 56 & 0 & 0 & 0 \\
\hline 5 & Meiza & nayah Putri & Pendidikan Pancasila & & 0 & 0 & 0 & 0 & 90 & 0 & 0 & 0 \\
\hline
\end{tabular}

Gambar 15. Lihat Nilai

\subsection{Halaman Utama Siswa}

Halaman utama siswa adalah halaman yang pertama kali muncul saat siswa berhasil login kedalam sistem.

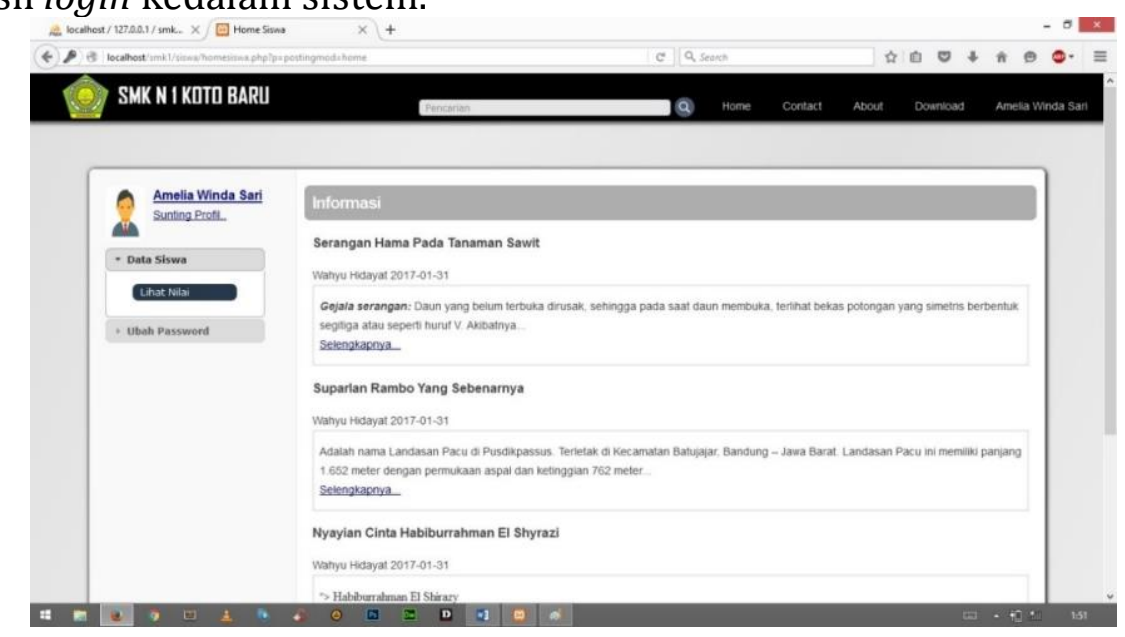

Gambar 16. Halaman Utama Siswa 


\subsection{Halaman Lihat Nilai Siswa}

Pada halaman lihat nilai siswa, siswa bisa melihat semua nilai yang telah dicapai pada masing - masing pelajaran berdasarkan tahun ajaran yang dipilih siswa tersebut.

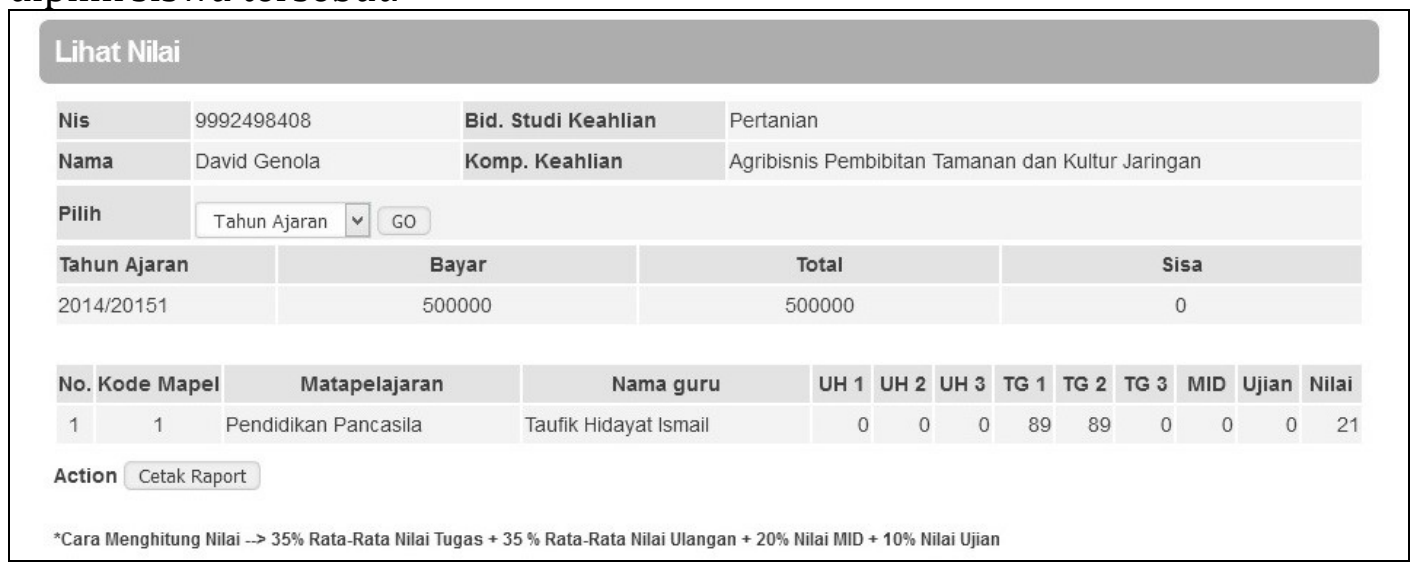

Gambar 17. Lihat nilai siswa

\subsection{Rapor Siswa}

Rapor siswa adalah hasil output dari sistem ini yang berupa laporan mengenai nilai yang didapat dalam proses pembelajaran selama satu semester.

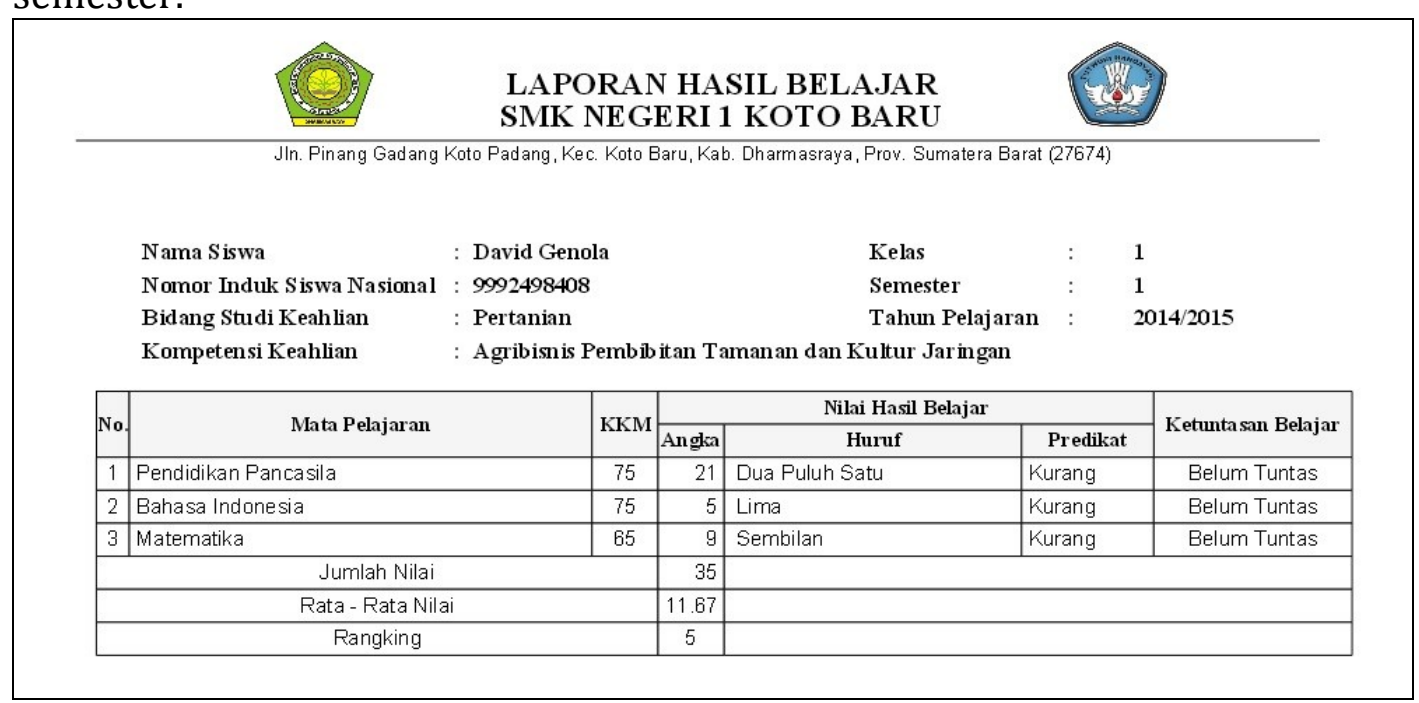

\section{Gambar 18. Rapor Siswa}

\section{KESIMPULAN}

Berdasarkan penelitian yang telah dilakukan mengenai analisa perancangan perangkat lunak pengolahan data akademik di SMK N 1 Koto Baru berbasis web, maka dapat disimpulkan bahwa sistem yang dibangun menyediakan beberapa fasilitas bagi para siswa untuk mengunduh bahan ajar yang disediakan oleh guru, melihat nilai, mencetak laporan nilai. Sedangkan bagi para guru disediakanya fasilitas untuk menggunggah bahan ajar, pengolahan nilai. Sistem yang dibangun juga mempermudah dan mempercepat proses pengolahan data nilai siswa, pembayaran uang sekolah 
siswa dalam hal menginformasikan dan pencarian data-data yang berkaitan akademik SMK N 1 Koto Baru.

\section{DAFTAR PUSTAKA}

[1] Anisya, A., \& Hidayat, W. "Analisa Perancangan Aplikasi Pengolahan Data Akademik Berbasis Web”, Jurnal TeknoIf, ISSN 2338-2724, 5(2), (2017).

[2] Defisanty, V, "Rekayasa Perangkat Lunak Berbasis Ajax Untuk Pengolahan Data Siswa Di SDN 02 Cupak Tengah Kecamatan Pauh”, Padang, Institut Teknologi Padang, (2015).

[3] Fathansyah, "Sistem Basis Data. Bandung: Informatika", (2004).

[4] Herawati, Y., "Rekayasa Perangkat Lunak Untuk Penjualan Perlengkapan Pengantin Adat Minangkabau Berbasis Web", Padang: Institut Teknologi Padang, (2013).

[5] Isa, I., "Sistem Informasi", Jakarta: Graha Ilmu, (2012).

[6] Nugroho, A., "Rekayasa Perangkat Lunak Berorientasi Objek dengan Metode USDP”, Andi, (2010).

[7] Saraswati, E., "Sistem Informasi Akademik Berbasis Web Pada Sekolah Menengah Pertama Negeri 3 Pringkuku", Indonesian Journal On Networking and Security - IJNS, (Volume 2 No 4 - Oktober 2013, ISSN: 2302-5700) .

[8] Simarmata, J, “Rekayasa Perangkat Lunak”, Andi, (2010).. 